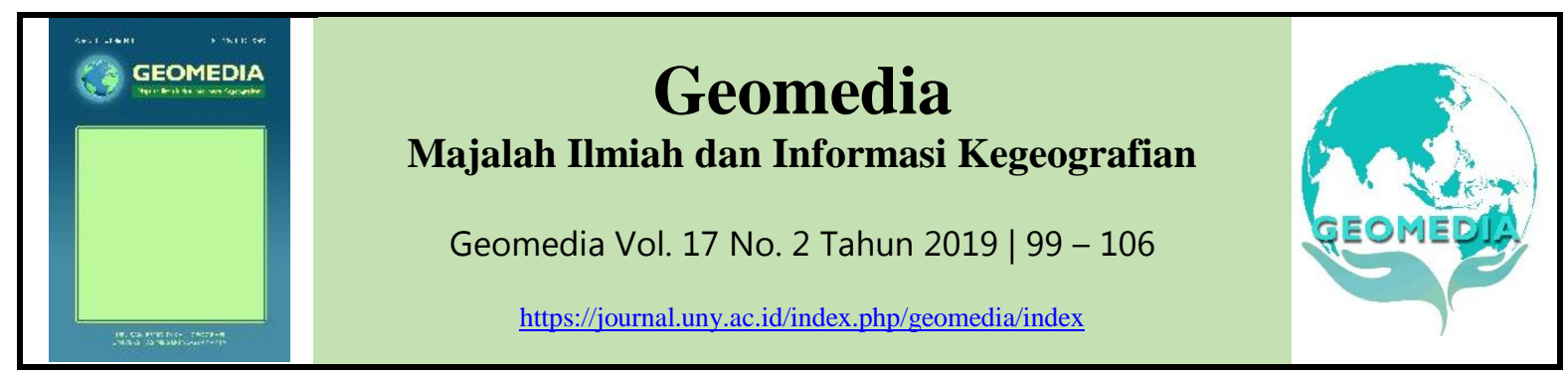

\title{
Persepsi Masyarakat Terhadap Penanaman Cemara Laut (Casuarina Equisetifolia L.) di Lahan Pasir Pantai Selatan Kabupaten Bantul Sebagai Upaya Mitigasi Bencana
}

\author{
Suhadi Purwantara ${ }^{1^{*}}$, Nurul Khotimah, Agus Sudarsono \\ Universitas Negeri Yogyakarta, Yogyakarta, Indonesia \\ ${ }^{1}$ suhadi_p@uny.ac.id* \\ *korespondensi penulis
}

\begin{tabular}{ll}
\hline Informasi artikel & A B S T R A K \\
\hline Sejarah artikel & Penelitian ini bertujuan untuk mengetahui (1) persepsi masyarakat \\
Diterima & terhadap penanaman cemara di lahan pasir pantai selatan Kabupaten \\
Revisi & Bantul, (2) persepsi masyarakat terhadap mitigasi bencana, dan (3) \\
Dipublikasikan $:$ & persepsi masyarakat terhadap penanaman cemara laut sebagai upaya \\
\hline Kata kunci: & mitigasi bencana. Penelitian ini merupakan penelitian deskriptif yang \\
Persepsi Masyarakat & dilaksanakan di pantai selatan Kabupaten Bantul di antara Muara Sungai \\
Cemara Laut & Opak dan Sungai Progo. Populasi penelitian adalah seluruh masyarakat di \\
Mitigasi Bencana & wilayah Pantai Samas, Pantai Baru, Pantai Gua Cemara, Pantai Kuwaru, dan \\
& Pantai Pandansimo. Sampel penelitian ditentukan secara quota sampling, \\
& yaitu sebanyak 60 responden. Data dikumpulkan melalui metode \\
& observasi, wawancara, dan dokumentasi. Teknik analisis yang digunakan \\
& adalah analisis deskriptif kuantitatif. Hasil dari penelitian menunjukkan \\
& bahwa (1) Persepsi masyarakat terhadap penanaman cemara laut di lahan \\
& pasir pantai selatan Kabupaten Bantul, yaitu sebanyak 85\% responden \\
mengatakan bahwa tanaman cemara laut memberikan manfaat baik, & sedangkan sisanya 20\% mengatakan manfaat sedang (2) Persepsi \\
& masyarakat terhadap mitigasi bencana, yaitu semua responden (100\%) \\
mengetahui arti bencana dan mengetahui potensi bencana di wilayahnya, & dan (3) Persepsi masyarakat terhadap penanaman cemara laut sebagai \\
& upaya mitigasi bencana, yaitu sebanyak 90\% responden mengatakan \\
& bahwa fungsi cemara laut adalah untuk mitigasi bencana.
\end{tabular}

Keywords:

Public Perception

Casuarina Equisetifolia L.

Disaster Mitigation

\section{A B S T R A C T}

This study aims to determine (1) community perceptions of Casuarina Equisetifolia L. planting in the southern coastal sandy area of Bantul Regency, (2) community perceptions of disaster mitigation, and (3) community perceptions of Casuarina Equisetifolia L. planting as disaster mitigation efforts. This research is a descriptive study carried out on the southern coast of Bantul Regency between the Opak River Estuary and the Progo River. The study population was all communities in the Samas Beach, Baru Beach, Gua Cemara Beach, Kuwaru Beach, and Pandansimo Beach. The research sample was determined by quota sampling, as many as 60 respondents. Data collected through observation, interviews, and documentation. The analysis technique used is quantitative descriptive analysis. The results of the study show that (1) public perception of the planting of Casuarina Equisetifolia L. in the southern coastal sandy area of Bantul Regency, as many as $85 \%$ of respondents said that Casuarina Equisetifolia L. plants provided good benefits, while the remaining $20 \%$ said moderate benefits (2) community perception of mitigation disaster, i.e. all respondents (100\%) know the meaning of disaster and know the potential of a disaster in their area, and (3) community perception of Casuarina Equisetifolia L. planting as a disaster mitigation effort, as many as $90 \%$ of respondents said that the function of Casuarina Equisetifolia $L$. is to mitigate disasters. 


\section{Pendahuluan}

Lahan pantai merupakan bentuk tanah mineral yang didominasi oleh ordo Entisols dan biasanya termasuk dalam lahan marjinal yang bersifat dinamis, sehingga jika tidak segera dikelola akan menyebabkan kerusakan permanen (Harjadi dan Miardi, 2013). Lahan di pantai selatan Kabupaten Bantul didominasi oleh material yang berasal dari hasil erupsi Gunung Merapi yang diangkut oleh aliran dari Sungai Opak dan Sungai Progo sehingga pantai tersebut dapat dikategorikan sebagai pantai berpasir. Terdapat hubungan antara pasokan butir-butir pasir dari hasil abrasi pantai oleh ombak menuju pantai dan dari gisik di pantai selatan Kabupaten Bantul. Hubungan ini terjadi karena hasil erosi angin ke arah daratan. Wujud nyata dari proses ini adalah terbentuknya gumuk pasir di sepanjang pantai selatan Kabupaten Bantul. Hal ini menyebabkan lahan pantai berpasir di wilayah ini menjadi semakin marjinal, baik di wilayah itu sendiri maupun wilayah di belakangnya. Kondisi lahan ini dapat dipengaruhi oleh faktor biofisik yang secara alami kurang mendukung maupun upaya penanganan yang belum optimal. Apabila kondisi ini tidak segera ditangani maka dapat menimbulkan dampak negatif di lahan tersebut.

Lahan pantai selatan Kabupaten Bantul telah diupayakan pengelolaan dan rehabilitasi lahan berpasir melalui penanaman tenaman tanggul angin atau penahan angin berupa cemara laut (Casuarina equisetifolia L.). Penanaman tersebut merupakan tindakan preventif untuk mencegah terjadinya abrasi pantai. Abrasi pantai merupakan erosi di wilayah pantai seperti hilangnya daratan karena kekuatan alam berupa aksi gelombang, arus pasang surut, atau deflasi yaitu hilangnya material di pantai yang disebabkan oleh gerakan angin (Prasetyo, 2004). Abrasi dapat mengancam garis pantai mundur ke belakang. Upaya vegetatif penanaman cemara laut dapat dilihat imbasnya, yaitu rimbunnya keberadaan cemara laut di lahan pantai selatan Kabupaten Bantul. Kondisi ini berakibat adanya pengembangan tempat wisata baru yang ditanami cemara laut tersebut. Tempat tersebut seperti Pantai Baru, Pantai Gua Cemara, dan Pantai Kuwaru. Objek wisata tesebut mengandalkan keteduhan pohon cemara laut.

Pengelolaan tempat wisata saat ini tidak sesuai dengan tujuan rehabilitasi kawasan pantai, yaitu untuk penghijauan, pematah angin, mencegah abrasi, membentuk gumuk pasir, menyerap karbondioksida, dan terutama mitigasi bencana tsunami akibat gempa bumi. Mitigasi adalah kegiatan pra bencana yang merupakan bagian dari siklus manajemen bencana. Kegiatan ini sangat penting karena merupakan modal dalam menghadapi bencana dan pasca bencana tetapi sering dilupakan masyarakat. Diperlukan pembenahan kegiatan mitigasi bencana khususnya bagi masyarakat, yaitu membenahi perilaku/tindakan masyarakat dan menyadari bahwa manusia adalah bagian dari lingkungan. Persepsi masyarakat menjadi sangat penting untuk upaya mitigasi bencana. Persepsi merupakan aktifitas yang terintegrasi dalam diri individu (Walgito, 2003). Persepsi dapat ditimbulkan karena perasaan, kemampuan berpikir, pengalaman individu yang tidak sama, sehingga hasil presepsi yang timbul dari suatu stimulus yang sama kemungkinan berbeda antara individu yang satu dengan individu yang lain.

Persepsi di masyarakat melalui pengetahuan (membaca) maupun peristiwa yang dialami memungkinkan masyarakat dapat mengetahui tindakan yang baik dan buruk untuk menjaga pelestarian lingkungan sekitar pantai. Berdasarkan uraian tersebut maka penting untuk diketahuinya persepsi masyarakat terhadap penanaman cemara laut (Casuarina equisetifolia L.) di lahan pasir pantai selatan Kabupaten Bantul sebagai upaya mitigasi bencana.

Tujuan dari penelitian ini adalah mengetahui persepsi masyarakat terhadap penanaman cemara laut di lahan pasir pantai selatan Kabupaten Bantul, mengetahui persepsi masyarakat terhadap mitigasi bencana, dan mengetahui persepsi masyarakat terhadap penanaman cemara laut sebagai upaya mitigasi bencana. 


\section{Metode}

Penelitian ini merupakan penelitian deskriptif untuk menggambarkan keadaan atau data yang diperoleh di lapangan. Lokasi penelitian dilaksanakan di Pantai Selatan Kabupaten Bantul di antara Muara Sungai Opak dan Sungai Progo yang dijadikan kawasan wisata cemara laut yaitu Pantai Samas, Pantai Baru, Pantai Gua Cemara, Pantai Kuwaru, dan Pantai Pandansimo. Penelitian dilaksanakan pada bulan Mei - Oktober 2014.

Populasi penelitian ini adalah masyarakat wilayah Pantai Samas, Pantai Baru, Pantai Gua Cemara, Pantai Kuwaru, dan Pantai Pandansimo. Sampel penelitian ini adalah masyarakat di wilayah pantai yang menjadi daerah penelitian yang ditentukan secara kuota sampling, yaitu sebanyak 60 responden.

Teknik pengumpulan data melalui observasi, wawancara, dan dokumentasi. Analisis dilakukan dengan kegiatan editing, koding, dan tabulasi. Teknik analisis yang digunakan adalah deskriptif kuantitatif dengan menggunakan pie diagram untuk menggambarkan kondisi di lapangan.

\section{Hasil dan pembahasan}

Kabupaten Bantul merupakan salah satu kabupaten di DIY yang pada bagian selatannya berbatasan dengan pantai, bagian timur berbatasan dengan Kabupaten Gunung Kidul, dan bagian barat dengan Kabupaten Kulonprogo. Pantai yang dijadikan lokasi penelitian adalah pantai yang terletak di antara Muara Sungai Opak dan Sungai Progo. Pantai tersebut adalah kawasan wisata dengan adanya penanaman cemara laut, yaitu Pantai Samas dan Pantai Gua Cemara di Kecamatan Sanden, Pantai Baru, Pantai Kuwaru, dan Pantai Pandansimo yang terletak di Kecamatan Srandakan.

Lahan pasir di pantai-pantai tersebut memiliki potensi menjadi lahan marjinal. Adanya penanaman cemara laut, memungkinkan mengurangi potensi tersebut. Upaya mitigasi bencana tersebut salah satunya adalah mengembangkan persepsi masyarakat tentang pemanfaatan cemara laut di sekitar pantai. Persepsi ini dapat diperoleh dari pengetahuan, peristiwa yang dialami, dan dari membaca. Harapannya hal tersebut dapat membantu masyarakat dalam menjaga pelestarian lingkungan sekitar pantai.

\section{Persepsi Masyarakat Terhadap Penanaman Cemara Laut}

Persepsi masyarakat terhadap penanaman cemara laut di lahan pasir pantai selatan Kabupaten Bantul dapat dilihat dari pengenalan masyakarat terhadap tanaman cemara laut, pengetahuan masyarakat terkait pihak yang menanam cemara laut, persepsi masyarakat terhadap kondisi, kebermanfaatan, pengetahuan masyarakat terkait dengan pengelolaan dan pelestarian tanaman cemara laut, serta pengetahuan masyarakat terhadap pihak yang mengatasi permasalahan tanaman cemara laut yang rusak atau mati.

Berdasarkan hasil penelitian, diketahui bahwa seluruh masyarakat mengenal tanaman cemara laut ini. Keberadaan cemara laut di lahan pasir pantai selatan Kabupaten Bantul cukup dikenal oleh masyarakat. Pengenalan masyarakat terhadap keberadaan tanaman cemara laut bersumber dari mengetahui sendiri, diberitahu oleh teman, dan diberitahu oleh pemerintah.

Data sumber informasi keberadaan tanaman cemara laut bagi masyarakat ditunjukkan oleh Gambar 1.

Sumber Informasi Keberadaan Tanaman Cemara Laut (\%)

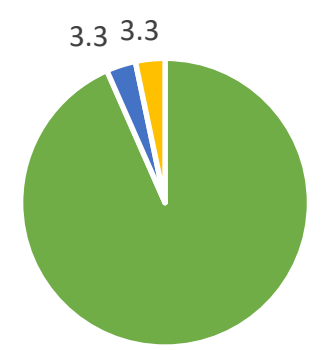

93.4

Mengetahui Sendiri

- Diberitahu oleh teman

- Diberitahu oleh pemerintah

Gambar 1. Sumber Informasi keberadaan tanaman cemara laut

Sumber: analisis lapangan tahun 2014 
Berdasarkan Gambar 1 diketahui bahwa 93,4\% masyarakat mengetahui keberadaan tanaman cemara laut. Sisanya mengetahui keberadaan tanaman cemara laut melalui pemberitahuan dari teman dan pemerintah. Pengetahuan masyarakat ini berdampak pada persetujuan mereka terhadap penanaman cemara laut. Menurut masyarakat penanaman cemara laut ini dapat menahan angin dan abrasi air laut.

Data pihak yang menanam tanaman cemara laut ditunjukkan oleh Gambar 2.

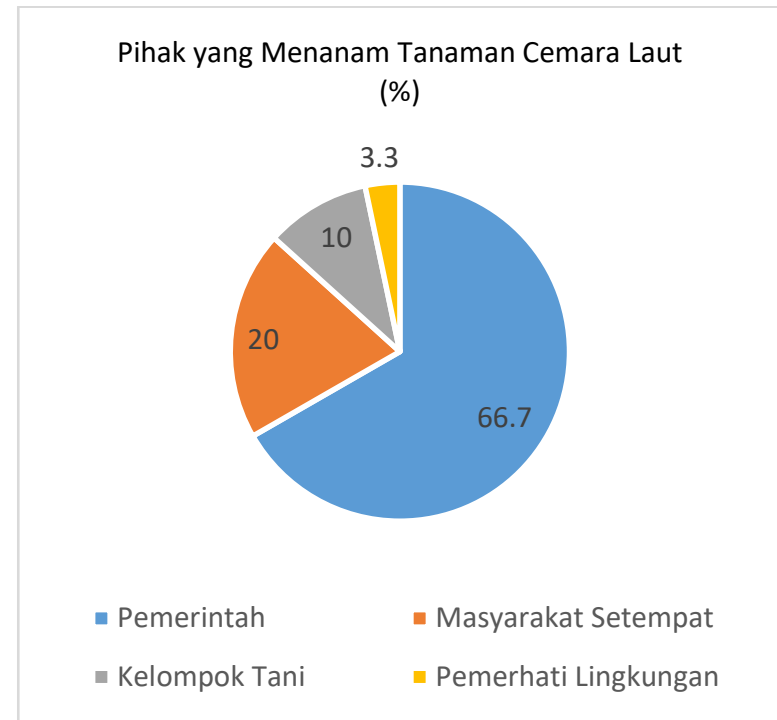

Gambar 2. Pihak yang menanam tanaman cemara laut

Sumber: analisis lapangan tahun 2014

Berdasarkan Gambar 2 diketahui bahwa penanaman pohon cemara laut didominasi oleh pemerintah yaitu sebesar $66,7 \%$, yang kedua adalah masyarakat setempat yaitu sebesar $20 \%$, yang ketiga adalah kelompok tani yaitu sebesar $10 \%$, dan yang terakhir adalah pemerhati lingkungan sebesar 3,3\%. Menurut masyarakat, pemerintah yang terlibat dalam penanaman pohon cemara laut ini adalah Dinas Kelautan dan Perikanan (DKP), Dinas Pertanian dan Kehutanan (Dipertahut), Badan Lingkungan Hidup (BLH), dan Pemerintah Daerah (Pemda). Pemerintah juga aktif melibatkan masyarakat dalam pelaksanaan penanaman cemara laut agar ikut serta dalam menjaga lingkungan pantai agar tetap lestari dan berkelanjutan. Penanaman dilakukan di lahan Sultan Ground. Tanah tersebut merupakan tanah yang bisa dikuasai oleh masyarakat dan penggunaan serta pemanfaatannya harus mendapatkan ijin terlebih dahulu dari pihak keraton. Meskipun demikian, pemanfaatan tanah Sultan Ground sebagian besar tanpa ada izin dari keraton, salah satu contohnya adalah pemanfaatan untuk objek wisata pantai di pesisir selatan Kabupaten Bantul.

Data kondisi cemara laut di sekitar pantai ditunjukkan oleh Gambar 3.

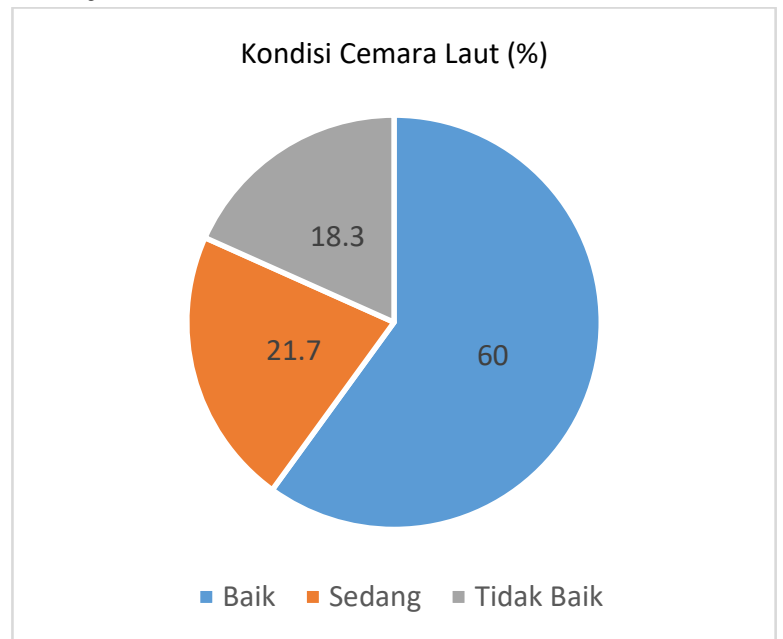

Gambar 3. Kondisi Cemara Laut di pantai Selatan Kabupaten Bantul

Sumber: analisis lapangan tahun 2014

Berdasarkan Gambar 3 diketahui bahwa menurut masyarakat kondisi cemara laut umumnya baik. Sebanyak $60 \%$ masyarakat menyatakan kondisi cemara laut baik, dimungkinkan karena di sekitar pantai terlihat barisan tanaman cemara laut yang tumbuh dengan baik. Meskipun demikian sebanyak 21,7\% masyarakat menyatakan bahwa kondisi cemara laut dalam kondisi sedang, dan sisanya sebanyak 18,3\% menyatakan kondisi cemara laut tidak baik.

Data persepsi masyarakat terhadap kebermanfaatan cemara laut ditunjukkan oleh Gambar 4. 
Persepsi masyarakat terhadap kebermanfaatan cemara laut (\%)

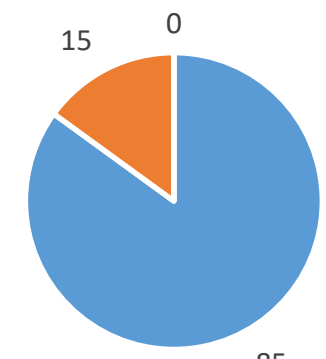

85

- Baik $\quad$ Sedang $\backsim$ Tidak Baik

Gambar 4. Persepsi masyarakat terhadap kebermanfaatan cemara laut

Sumber: analisis lapangan tahun 2014

Berdasarkan Gambar 4 diketahui bahwa sebagian besar masyarakat merasa bahwa kebermafaatan cemara laut ini baik, yaitu sekitat $85 \%$. Sisanya merasa bahwa kebermanfaatan cemara laut dalam kategori sedang. Tidak ada satu pun masyarakat yang merasa bahwa cemara laut tidak baik manfaatnya. Kebermanfaatan cemara laut yang dirasakan oleh banyakan masyarakat dimungkinkan karena tanaman tersebut berpotensi dikembangkan dalam upaya konservasi kawasan pesisir, yaitu sebagai penahan angin dan abrasi air laut seperti di kawasan pantai yang ada di pesisir selatan Kabupaten Bantul. Meskipun demikian, masyarakat menyebutkan bahwa sejumlah cemara laut di antara barisan tanaman cemara laut masih ditemui tanaman cemara laut yang rusak bahkan mati.

Menurut masyarakat, pihak yang melakukan pengelolaan dan pelestarian tanaman cemara laut adalah masyarakat setempat dan kelompok tani. Hal ini dimungkinkan masyarakat beranggapan bahwa pemerintah dan pemerhati lingkungan hanya berpartisipasi dalam penanaman cemara laut, tetapi dalam pengelolaan dan pelestarian tanaman cemara laut cenderung dilakukan oleh masyarakat setempat dan kelompok tani yang tinggal di sekitar pantai mengingat sehari-hari mereka berinteraksi dengan lingkungannya.
Data persepsi masyarakat terhadap pengelolaan dan pelestarian cemara laut ditunjukkan oleh Gambar 5.

Persepsi Masyarakat terhadap Pengelolaan dan Pelestarian Cemara Laut (\%)

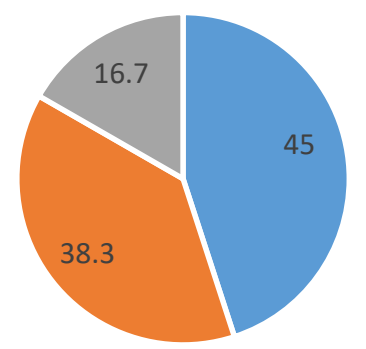

- Baik $\backsim$ Sedang $\square$ Tidak Baik

Gambar 5. Persepsi masyarakat terhadap pengelolaan $\&$ pelestarian cemara laut

Sumber: analisis lapangan tahun 2014

Berdasarkan Gambar 5 diketahui bahwa hampir setengah dari masyarakat yaitu sekitar 45\% menyatakan bahwa pengelolaan dan pelestarian cemara laut baik, diikuti dengan tingkat sedang $38,3 \%$, dan tidak baik $16,7 \%$. Banyak responden yang menyatakan bahwa pelestarian dan pengelolaan cemara laut baik karena jumlah tanaman cemara di sekitar pantai tumbuh dengan baik dibandingkan dengan tanaman yang rusak atau mati. Hampir seluruh masyarakat beranggapan bahwa penanaman cemara laut sudah sesuai dengan karakteristik pantai karena tanaman tersebut tumbuh dengan baik. Hal ini membutktikan bahwa tanaman ini sesuai atau cocok ditanam pada lahan pasir pantai. Menurut sebagian besar masyarakat sudah terdapat upaya untuk mengatasi cemara laut yang rusak ataupun mati.

Data pihak yang melakukan upaya mengatasi cemara laut yang rusak atau mati ditunjukkan oleh Gambar 6. 
Pihak yang Mengatasi Cemara Laut yang Rusak atau Mati (\%)

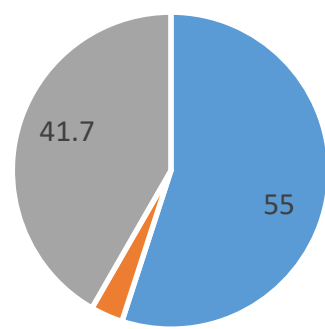

3.3

- Masyarakat = Kelompok Tani = Tidak Ada

Gambar 6. Pihak yang melakukan upaya mengatasi cemara laut yang rusak atau mati

Sumber: analisis lapangan tahun 2014

Berdasarkan Gambar 6 diketahui bahwa sebagian masyarakat mengatakan bahwa pihak yang mengatasi cemara laut yang rusak atau mati adalah masyarakat (55\%) dan $41,7 \%$ menyatakan bahwa tidak ada yang mengatasi cemara laut yang rusak dan mati atau dibiarkan saja. Sisanya menyebutkan diatasi oleh kelompok tani (3,3\%). Menurut masyarakat, upaya yang dilakukan adalah dengan cara ditanami kembali, dipupuk, dan dibiarkan saja. Kebanyakan tanaman cemaran laut ditanami kembali ketika rusak atau mati.

Berdasarkan keseluruhan data, diketahui bahwa pada umumnya masyarakat sudah mengetahui tentang tanaman cemara laut. Pengetahuan ini didapatkan dari pengalaman masyarakat dalam membaca kondisi lingkungan. Masyarakat sekitar pantai selatan Kabupaten Batul merasakan manfaat adanya tanaman cemara laut karena dapat menjadi penahan angin dan abrasi yang terjadi di sekitar pantai. Selain itu, juga sudah terdapat upaya pengelolaan dan pelestarian cemara laut meskipun lebih banyak dilakukan oleh masyarakat sekitar dan kelompok tani.

\section{Persepsi Masyarakat Terhadap Mitigasi Bencana}

Persepsi masyarakat di pantai selatan Kabupaten Bantul terhadap mitigasi bencana diketahui berdasarkan pengetahuan masyarakat terhadap potensi bencana di wilayah pesisir dan dampak bencana terhadap lahan pesisir.

Berdasarkan data yang didapatkan, seluruh masyarakat mengetahui arti bencana. Masyarakat menganggap bencana sebagai suatu peristiwa yang dapat menimbulkan kerugian bagi mereka, baik kerugian harta benda, maupun korban jiwa. Masyarakat juga mengetahui potensi bencana di wilayah pesisir.

Data Potensi bencana di wilayah pesisir berdasarkan pendapat masyarakat ditunjukkan oleh Gambar 7.

Potensi Bencana di Wilayah Pesisir Menurut Masyarakat (\%)

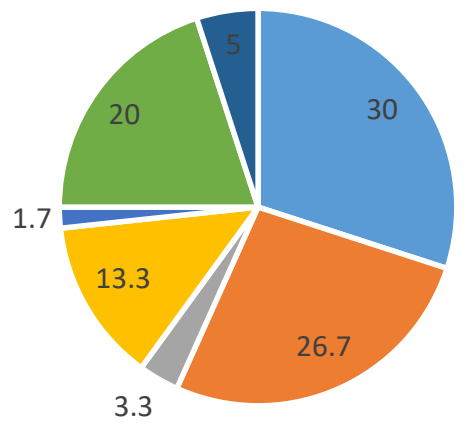

- Tsunami, gelombang besar, abrasi

- Tsunami, gelombang besar, abrasi

- Abrasi

- Tsunami, abrasi

- Tsunami, gelombang besar, abrasi, badai

- Tsunami, abrasi, gempa bumi

- Tsunami, gempa bumi

Gambar 7. Potensi Bencana yang dapat terjadi di wilayah pesisir menurut masyarakat Sumber: analisis lapangan tahun 2014

Berdasarkan Gambar 7 diketahui bahwa menurut masyarakat, tsunami, gelombang besar, abrasi, dan gempa bumi merupakan potensi bencana di wilayah pesisir yang mengancam mereka. Menurut masyarakat, wilayah sekitar pantai pernah terjadi bencana. Bencana yang paling banyak terjadi adalah abrasi dan gempa bumi. Meskipun demikian, 53,3\% masyarakat 
menyatakan tidak pernah menjadi korban bencana.

Data dampak bencana yang mengakibatkan lahan pesisir menjadi rusak menurut masyarakat ditunjukkan oleh Gambar 8.

Dampak Bencana Mengakibatkan Lahan Pesisir Menjadi Rusak (\%)

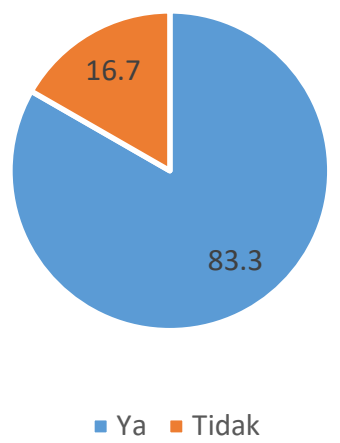

Gambar 8. Dampak Bencana Mengakibatkan Lahan Pesisir Menjadi Rusak

Sumber: analisis lapangan tahun 2014

Berdasarkan Gambar 8 diketahui bahwa 83,3\% masyarakat merasa bahwa bencana berdampak pada kerusakan lahan pesisir. Umumnya masyarakat sudah mengetahui potensi bencana di daerah pesisir, seperti jenis bencana dan dampak dari bencana tersebut.

\section{Persepsi Masyarakat Terhadap Penanaman} Cemara Laut sebagai Upaya Mitigasi Bencana

Persepsi masyarakat di pantai selatan Kabupaten Bantul terhadap penanaman cemara laut sebagai upaya mitigasi bencana dapat diketahui melalui pengetahuan masyarakat terhadap mitigasi bencana dan pengetahuan masyarakat terhadap fungsi cemara laut untuk mitigasi bencana.

Kebanyakan masyarakat mengetahui tentang mitigasi bencana. Hanya sedikit masyarakat yang tidak mengetahuinya. Bagi mereka, mitigasi bencana merupakan upaya pencegahan terjadinya bencana.

Data masyarakat yang mengetahui tentang mitigasi bencana ditunjukkan oleh Gambar 9 .
Pengetahuan Masyarakat tentang Mitigasi Bencana (\%)

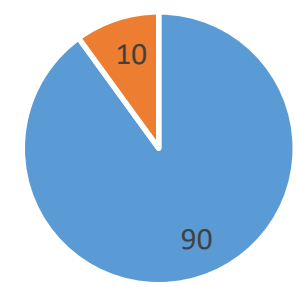

- Ya - Tidak

Gambar 9. Pengetahuan masyarakat tentang mitigasi bencana

Sumber: analisis lapangan tahun 2014

Berdasarkan Gambar 9 diketahui bahwa 90\% masyarakat menyatakan mengetahui tentang mitigasi bencana. Masyarakat juga menyatakan bahwa mereka pernah mendapatkan sosialisasi mitigasi bencana. Kegiatan ini dilaksanakan oleh pemerintah setempat. Menurut sebagian besar masyarakat sosialisasi ini tidak disertai dengann simulasi mitigasi bencana. Meskipun demikian, sebagian besar masyarakat menganggap bahwa pelaksanaan sosialisasi mitigasi bencana oleh pemerintah dapat dikategorikan baik.

Data pengetahuan masyarakat tentang fungsi cemara laut untuk mitigasi bencana ditunjukkan oleh Gambar 10.

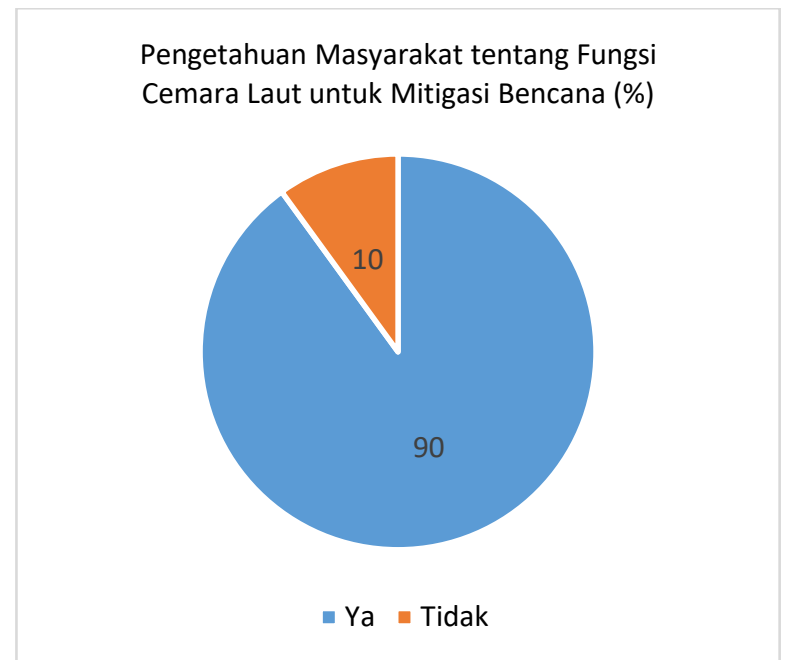

Gambar 10. Pengetahuan masyarakat tentang fungsi cemara laut untuk mitigasi bencana Sumber: analisis lapangan tahun 2014 
Berdasarkan Gambar 10 diketahui bahwa $90 \%$ dari sampel masyarakat yang diambil memahami tentang fungsi cemara laut untuk mitigasi bencana. Kebanyakan dari masyarakat menyebutkan bahwa fungsi nyata dari cemara laut terhadap mitigasi bencana adalah kemampuan tanaman untuk menahan gelombang. Fungsi ini dapat mengurangi abrasi yang terjadi di pinggir pantai. Masyarakat juga kebanyakan setuju terkait dengan penanaman cemara laut karena sesuai dengan fungsinya, salah satunya adalah untuk mitigasi bencana yang baik.

Persepsi masyarakat terhadap penanaman cemara laut sebagai upaya mitigasi bencana sudah baik. Kebanyakan masyarakat sudah menyadari fungsi tersebut. Persepsi ini mungkin didapatkan oleh masyarakat karena pengalaman atau pun penglihatan masyarakat sehari-hari tentang cemara laut.

Berdasarkan ketiga komponen yang diukur untuk mengetahui persepsi masyarakat terhadap penanaman cemara laut di lahan pasir pantai selatan Kabupaten Bantul sebagai upaya mitigasi bencana diketahui bahwa persepsi ini sudah terstruktur cukup baik di kalangan masyarakat yang tinggal di sekitar pesisir pantai. Hampir seluruh masyarakat mengetahui tentang cemara laut termasuk dengan fungsinya sebagai upaya mitigasi bencana di pantai selatan Kabupaten Bantul. Harapannya dengan adanya persepsi yang cukup baik di kalangan masyarakat pantai selatan Kabupaten Bantul dapat menjadi salah satu upaya yang akan berdampak pada berkurangnya kerugian yang timbul dari bencana.

Kebanyakan masyarakat beranggapan fungsi cemara laut sebagai perindang, penyejuk, keindahan, penahan angin, penahan abrasi, dan penahan tsunami. Selain fungsi-fungsi tersebut, penanaman cemara laut juga merupakan bentuk upaya konservasi lahan pasir di pantai selatan Kabupaten Bantul. Harapannya adalah masyarakat dapat terus menjaga lingkungan sekitar pantai untuk pengelolaan wisata berkelanjutan dengan memperhatikan kelestarian tanaman tersebut. Selain itu, pemerintah juga diharapkan untuk aktif meningkatkan upaya pelatihan dan simulasi mitigasi bencana di daerah pantai selatan Kabupaten Bantul.

\section{Simpulan}

Persepsi masyarakat terhadap penanaman cemara laut di lahan pasir pantai selatan Kabupaten Bantul: sebanyak $85 \%$ responden mengatakan bahwa tanaman cemara laut memberikan manfaat baik, sedangkan sisanya $15 \%$ mengatakan manfaat sedang. Persepsi masyarakat terhadap mitigasi bencana: semua responden (100\%) mengetahui arti bencana dan mengetahui potensi bencana di wilayahnya. Persepsi masyarakat terhadap penanaman cemara laut sebagai upaya mitigasi bencana: sebanyak $90 \%$ responden mengatakan bahwa fungsi cemara laut untuk mitigasi bencana

\section{Ucapan terima kasih}

Penulis mengucapkan terimakasih kepada Fakultas Ilmu Sosial yang telah membiayai penelitian ini melalui Dana DIPA Tahun Anggaran 2014

\section{Referensi}

Harjadi, Beny., dan Miardini, Arina. (2013). Penanaman Cemara Laut (Casuarina equisetifolia LINN) Sebagai Upaya Pencegahan Abrasi di Pantai Berpasir. Jurnal Penelitian Hutan dan Konservasi Alam. 7(5)

Peraturan Pemerintah No 21 Tahun 2008 tentang Penyelenggaraan Penanggulangan Bencana.

Prasetyo, Sigit B. 2004. Karakteristik Gelombang dan Pola Arus Pada Daerah Akresi dan Abrasi di Sepanjang Pantai Semarang. Semarang: Universitas Diponegoro.

Rakhmat, Jalaluddin. 2011. Psikologi Komunikasi. Bandung: Rosdakarya.

Triatmodjo, Bambang. 1999. Teknik Pantai. Yogyakarta: Betta offset.

Walgito, Bimo. 2003. Pengantar Psikologi Umum. Yoyakarta: Andi Offset. 